\title{
Direct effect of angiotensin II on in-vitro perfused rabbit ovary
}

\author{
T.-C. Kuo, K. Endo, A. M. Dharmarajan*, T. Miyazaki, S. J. Atlas and \\ E. E. Wallach
}

The Johns Hopkins University School of Medicine, Department of Gynecology and Obstetrics, Baltimore, MD 21205, USA

\begin{abstract}
Summary. The effects of angiotensin II (AII) and its receptor blocker, saralasin (SAR), on ovulation and oocyte maturation were investigated in an isolated, in-vitro perfused rabbit ovary. Ovulation and oocyte maturation were induced by AII in the absence of human chorionic gonadotrophin (hCG). SAR inhibited ovulation induced by AII or hCG, but not oocyte maturation. AII appears to play a critical role in follicle rupture, but not in resumption of oocyte meiosis.
\end{abstract}

Kelwords: angiotensin II; ovulation; ovary; oocyte maturation; saralasin; rabbit

\section{Introduction}

Human preovulatory follicular fluid concentrations of prorenin, renin and angiotensin II (AII) are higher than those in peripheral blood in gonadotrophin-stimulated and natural cycles (Fernandez et al., 1985; Culler et al., 1986; Glorioso et al., 1986; Lightman et al., 1987). The intracellular presence of renin and AII has been demonstrated in luteal, thecal, stromal and luteinized granulosa cells, but not in other granulosa cells (Lightman et al., 1988; Palumbo et al., 1989). Administration of saralasin (SAR), a specific AII receptor blocker, to gonadotrophin-stimulated rats has been reported to inhibit ovulation and oocyte maturation (Palumbo et al., 1988; Pellicer $e t$ al., 1988). AII has been demonstrated to stimulate ovarian steroidogenesis in rats (Pucell et al., 1987). Ovarian AII receptors have been localized autoradiographically on rat granulosa, theca, and luteal cells (Speth et al., 1986; Husain et al., 1987; Daud et al., 1988; Lightman et al., 1988). These receptors, predominantly on the granulosa cells, display cyclical variation over the rat oestrous cycle (Daud et al., 1988; Lightman et al., 1988). Although these findings raise the possibility of a role for AII in ovulation and oocyte maturation, controversy exists because AII receptors were not detected on rat granulosa cells containing luteinizing hormone ( $\mathrm{LH}$ ) receptors (Daud et al., 1989).

This study investigated whether All has a direct effect on isolated rabbit ovary in the absence of gonadotrophin and has a physiological role in the ovary. The major objective was to examine the effects of AII and its receptor blocker, SAR, on ovulation and oocyte maturation, using an in-vitro perfused ovary system. In addition, alterations in the follicular microvasculature following stimulation with AII or gonadotrophin were compared by scanning electron microscopy (SEM).

\section{Materials and Methods}

\footnotetext{
Animals. Twenty-nine sexually mature New Zealand White female rabbits weighing $3 \cdot 5-4.5 \mathrm{~kg}$ were caged individually for at least 3 weeks before use. Animals were given water and a diet of rabbit chow ad libitum. Rabbits were

${ }^{*}$ Corresponding author: Johns Hopkins Medical Institutions, 600 N. Wolfe Street, Park Building-B2-202, Baltimore, MD 21205, USA.
} 
anaesthetized with intravenous sodium pentobarbitone $(32 \mathrm{mg} / \mathrm{kg})$, treated with heparin sulphate ( $120 \mathrm{U} / \mathrm{kg})$ for anticoagulation and then subjected to laparotomy. All studies were performed in accordance with the National Institutes of Health (1985) Guide for the Care and Use of Laboratory Animals.

In-vitro perfusion. The cannulation procedure and perfusion apparatus have been described (Lambertsen et al., 1976; Kobayashi et al., 1981). Briefly, each ovarian artery was isolated and cannulated in situ after ligation of major anastomotic connections. Each ovary with its vein, cannulated artery and supportive connective tissue was removed and placed in the perfusion chamber. The perfusion system consisted of an ovarian perfusion chamber, a reservoir, an oxygenator and a pulsatile roller pump that maintained flow at $1.5 \mathrm{ml} / \mathrm{min}$, the approximate blood flow to the rabbit ovary (Ahren et al., 1972). Each ovary was perfused with $150 \mathrm{ml}$ of tissue culture medium 199 (TCM 199, M. A. Bioproducts, Walkersville, MD, USA) supplemented with $200 \mathrm{U}$ heparin sulphate, $20 \mathrm{U}$ insulin, $50 \mathrm{mg}$ streptomycin and $75 \mathrm{mg}$ penicillin $\mathrm{G} / \mathrm{l}$ ) at $37^{\circ} \mathrm{C}$ for $10.5 \mathrm{~h}$. Ovaries were examined at 15 -min intervals for evidence of follicular growth and rupture. In several experiments, arterial pressure was measured with a manometer at 3-h intervals over the course of perfusion. Ovulatory efficiency, the percentage of mature follicles $(\geqslant 1.5 \mathrm{~mm}$ in diameter) that proceed to rupture during perfusion, was calculated for each ovary. Ovulated ova and follicular oocytes from unruptured follicles were assessed for stage of maturity as described by Kobayashi et al. (1981).

Direct effects of AII on ovulation and oocyte maturation in the absence of gonadotrophins. AII (Sigma Chemical Co., St Louis, MO, USA) was added to the perfusate of each experimental ovary at $15 \mathrm{ng}, 1.5 \mu \mathrm{g}$ or $150 \mu \mathrm{g}$ for a final concentration of $0 \cdot 1,10$ or $1000 \mathrm{ng} / \mathrm{ml}$, respectively, at the onset of perfusion. The control ovaries received only the saline vehicle. AII administration was repeated $2 \mathrm{~h}$ later. Six ovaries were perfused for each dose. A total of 12 rabbits was used for this experiment.

Effects of SAR on AII-induced ovulation and oocyte maturation. One ovary of each of 4 rabbits was perfused with TCM 199 containing $1 \cdot 0 \mu \mathrm{g}$ of SAR $/ \mathrm{ml}\left(\left[\mathrm{Sar}^{1}, \mathrm{Val}^{5}, \mathrm{Ala}^{8}\right]-\mathrm{AII}\right.$, Sigma Chemical Co.); the contralateral control ovary was perfused with medium alone; $30 \mathrm{~min}$ after the onset of perfusion, $15 \mathrm{ng}$ AII was added to the perfusate and perfusion was continued for a further $10 \mathrm{~h}$.

Effects of SAR on hCG-induced ovulation and oocyte maturation. SAR $(1.0 \mu \mathrm{g} / \mathrm{ml}, 10 \mu \mathrm{g} / \mathrm{ml})$ was incorporated in the perfusate of experimental ovaries; medium alone was used for control ovaries. Thirty minutes later, 50 iu hCG (Pregnyl, Organon, West Orange, NJ, USA) was added to the perfusate of experimental and control ovaries. To investigate the effect of SAR alone, 7 ovaries were perfused with $10 \mu \mathrm{g} \mathrm{SAR} / \mathrm{ml}$ and exposed to saline vehicle in place of hCG. Thirteen rabbits were used for this experiment.

Morphology of preovulatory follicles treated with AII or $\mathbf{h C G}$. One ovary of each of 4 rabbits was perfused with $0.1 \mathrm{ng} \mathrm{AIl} / \mathrm{ml}$, while the contralateral ovary was perfused with $50 \mathrm{iu} \mathrm{hCG}$. The agent was added to the perfusate $30 \mathrm{~min}$ after the onset of ovarian perfusion. Perfusion was terminated $46 \mathrm{~h}$ after drug addition to obtain preovulatory follicles for scanning electron microscopy (SEM) (Kitai et al., 1985b).

Statistical analysis. Data were analysed using the $\chi^{2}$ test with Yates' correction (ovulatory efficiency and ovum stage) and ANOVA (time of ovulation).

\section{Results}

\section{Direct effects of AII on ovulation and oocyte maturation in the absence of gonadotrophins}

AII induced ovulation at all concentrations $(0 \cdot 1,10$, and $1000 \mathrm{ng} / \mathrm{ml})$, in the absence of $\mathrm{hCG}$. The greatest ovulatory efficiency $(75 \%)$ was observed at the highest dose tested (Table 1$)$. Increasing AII concentration reduced ovulation time, but the difference was not significant (Table 1). As the concentration of AII increased, the ovulated ova and follicular oocytes with germinal vesicle breakdown (GVBD) increased to $35 \cdot 1 \%$ and then declined to $17.5 \%$ (Table 1). AII did not affect arterial pressure during perfusion at the lower doses, 0.1 and $10 \mathrm{ng} / \mathrm{ml}$, while the peak pressure observed with $1000 \mathrm{ng} / \mathrm{ml}$ was no higher than the peak observed with the control (data not shown).

\section{Effects of SAR on AII-induced ovulation and oocyte maturation}

Ovulatory efficiency was significantly $(P<0 \cdot 05)$ lower when ovaries were perfused with AII plus SAR than with AII alone (Table 2). The interval from addition of agent to ovulation 
Table 1. Angiotensin II-induced ovulation in rabbits

\begin{tabular}{lcccc}
\hline & \multicolumn{4}{c}{ Angiotensin II $(\mathrm{ng} / \mathrm{ml})$} \\
& 0 & $0 \cdot 1$ & 10 & 1000 \\
\hline No. of ovaries perfused & 6 & 6 & 6 & 6 \\
Time to ovulation (h) & $7 \cdot 54 \pm 1 \cdot 71$ & $5 \cdot 72 \pm 0 \cdot 24$ & $5 \cdot 95 \pm 0 \cdot 31$ & $4 \cdot 74 \pm 0 \cdot 22$ \\
No. of mature follicles & 37 & 43 & 37 & 40 \\
No. of ovulated ova & 2 & 20 & 20 & 30 \\
$\quad$ No. showing GVBD & 0 & 7 & 8 & 6 \\
No. of follicular oocytes & 35 & 23 & 17 & 10 \\
$\quad$ No. showing GVBD & 2 & 8 & 5 & 1 \\
Total GVBD (\%) & $5 \cdot 4$ & $34 \cdot 9^{*}$ & $35 \cdot 1^{*}$ & $17 \cdot 5$ \\
Ovulatory efficiency $(\%)_{+}^{+}$ & $5 \cdot 4$ & $46 \cdot 5^{* *}$ & $54 \cdot 1^{* *}$ & $75 \cdot 0^{* *}$ \\
\hline
\end{tabular}

${ }^{*} P<0.01$ compared with control; ${ }^{* *} P<0.001$ compared with control.

TGVBD is germinal vesicle breakdown.

†Ovulatory efficiency is the percentage of mature follicles that rupture during perfusion.

Table 2. Saralasin inhibition of ovulation induced by $0.1 \mathrm{ng}$ angiotensin $\mathrm{II} / \mathrm{ml}$ in rabbits

\begin{tabular}{lcc}
\hline & \multicolumn{2}{c}{ Saralasin $(\mu \mathrm{g} / \mathrm{ml})$} \\
& 0 & 1 \\
\hline No. of ovaries perfused & 4 & 4 \\
Time to ovulation $(\mathrm{h})$ & $5 \cdot 08 \pm 0 \cdot 35$ & $7 \cdot 50 \pm 0 \cdot 52^{*}$ \\
No. of mature follicles & 24 & 29 \\
No. of ovulated ova & 10 & 3 \\
$\quad$ No. showing GVBD $\dagger$ & 3 & 0 \\
No. of follicular oocytes & 14 & 26 \\
$\quad$ No. showing GVBD & 4 & 4 \\
Total GVBD (\%) & $29 \cdot 2$ & $13 \cdot 8$ \\
Ovulatory efficiency $(\%) \ddagger$ & $41 \cdot 7$ & $10 \cdot 3^{* *}$ \\
\hline
\end{tabular}

$* P<0.005$.

$* * P<0.05$

†GVBD is germinal vesicle breakdown.

${ }_{+}$Ovulatory efficiency is the percentage of mature follicles that rupture during perfusion.

Table 3. Effect of saralasin on ovulation in rabbits in the presence and absence of human chorionic gonadotrophin (hCG)

\begin{tabular}{|c|c|c|c|c|}
\hline & \multicolumn{4}{|c|}{ hCG (iu) } \\
\hline & \multicolumn{3}{|c|}{50} & 0 \\
\hline & \multicolumn{3}{|c|}{ Saralasin $(\mu \mathrm{g} / \mathrm{ml})$} & \multirow[b]{2}{*}{10} \\
\hline & 0 & 1 & 10 & \\
\hline No. of ovaries perfused & 6 & 6 & 6 & 7 \\
\hline Time to ovulation (h) & $5.84 \pm 0.27$ & $5.90 \pm 0.29$ & $7 \cdot 02 \pm 0 \cdot 38^{*}$ & $8 \cdot 25$ \\
\hline No. of mature follicles & 37 & 32 & 49 & 47 \\
\hline No. of ovulated ova & 33 & 26 & 9 & 1 \\
\hline No. showing GVBD† & 26 & 19 & 9 & 0 \\
\hline No. of follicular oocytes & 4 & 6 & 26 & 44 \\
\hline No. showing GVBD & 3 & 4 & 21 & 1 \\
\hline Total GVBD (\%) & $78 \cdot 4$ & 71.9 & $85 \cdot 8$ & $2 \cdot 2$ \\
\hline Ovulatory efficiency $(\%)_{+}^{+}$ & $89 \cdot 2$ & $81 \cdot 3$ & $18 \cdot 4 * \S$ & $2 \cdot 1$ \\
\hline
\end{tabular}

${ }^{*} P<0.05,{ }^{* *} P<0.00 \mathrm{l}$ compared with 0 or $1 \mu \mathrm{g} / \mathrm{ml}$.

$\S P<0.01$ compared with saralasin $(10 \mu \mathrm{g} / \mathrm{ml})$ alone.

† GVBD is germinal vesicle breakdown.

$\ddagger$ Ovulatory efficiency is the percentage of mature follicles that rupture during perfusion. 

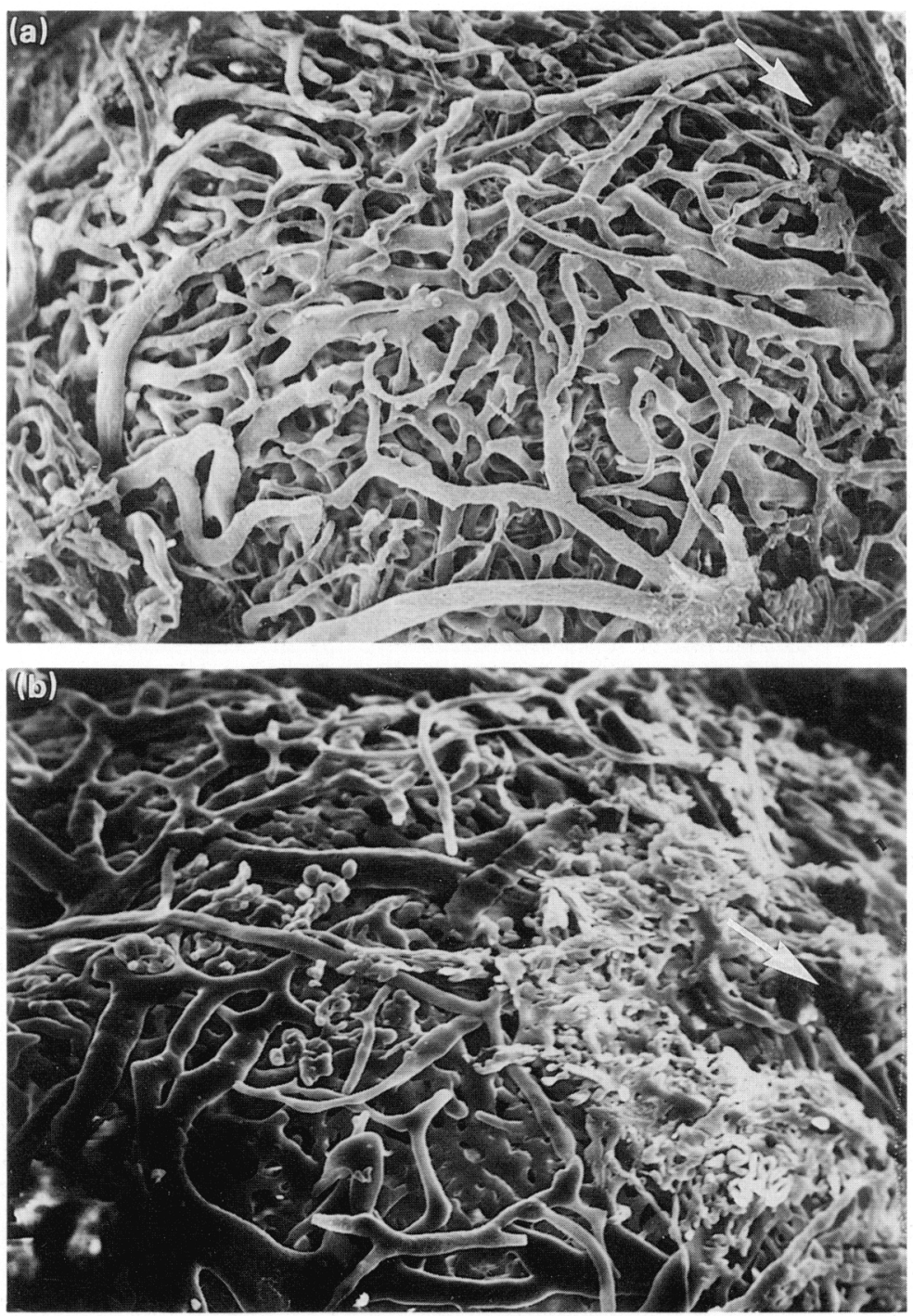

Fig. 1. Scanning electron microscopy of rabbit follicular microvascular casts $(\times 140)$. (a) Control ovary $6 \mathrm{~h}$ after ovulation induction with human chorionic gonadotrophin. Note the dilation of vessels and the filling defect at the apex of the follicle (arrow).

(b) Ovary induced to ovulate with $0.1 \mathrm{ng}$ angiotensin $\mathrm{II} / \mathrm{ml}, 4 \mathrm{~h}$ after drug addition. Vessels appear to be dilated, and a filling defect is apparent (arrow) as in control animals treated with hCG.

lengthened from $5.08 \pm 0.35$ h to $7.50 \pm 0.52 \mathrm{~h}$ during perfusion with SAR (Table 2). SAR did not significantly affect GVBD of ovulated ova or follicular oocytes (Table 2).

\section{Effects of SAR on hCG-induced ovulation and oocyte maturation}

Ovulatory efficiency was reduced to $18.4 \%(P<0.001)$ and the mean time to ovulation increased from $5.84 \pm 0.27 \mathrm{~h}$ to $7.02 \pm 0.38 \mathrm{~h}(P<0.02)$ when ovaries receiving hCG were perfused with $10 \mu \mathrm{g} \mathrm{SAR} / \mathrm{ml}$ (Table 3). hCG-induced GVBD in ovulated or follicular oocytes was not 
affected by SAR. SAR when given alone at $10 \mu \mathrm{g} / \mathrm{ml}$ had no effect on induction of ovulation or GVBD (Table 3).

\section{Morphology of preovulatory follicles treated with AII or hCG}

SEM revealed that the microvasculature of ovarian follicles in both groups displayed filling defects at the site of stigma formation and dilation of surrounding vessels (Fig. Ia, b). There was no apparent difference between the 2 agents and no evidence for pharmacological vasoconstriction in response to AII administration.

\section{Discussion}

The results of the present study, demonstrating that AII induces ovulation in the absence of gonadotrophin and that ovulation induced by hCG or AII can be inhibited by SAR, raise the possibility that specific AII receptors may be involved in ovulation in rabbits. The microvasculature in AII- and hCG-stimulated follicles was similar by SEM (Fig. 1), suggesting that AII administration does not cause pharmacological constriction of the follicular microvasculature. This was further supported by the perfusion pressure, which was not affected by AII administration. The perfusion system maintains a constant flow; therefore, changes in microvasculature, i.e. resistance, would have resulted in a change in pressure. The similarity in alteration of microvasculature and the $80 \%$ inhibition of hCG-induced ovulation in the presence of $10 \mu \mathrm{g} \mathrm{SAR} / \mathrm{ml}$ suggest that AII plays a critical role in the ovulatory cascade initiated by hCG. Our results confirm the findings of Pellicer et al. (1988) that SAR blocks hCG-induced ovulation in vivo.

AII induced meiotic resumption in ovulated ova and follicular oocytes. Although the effectiveness of AII was less than half that observed by stimulation with hCG, other nongonadotrophic agents (e.g. PGF-2 $\alpha$, plasminogen activator and bradykinin) that induce ovulation in this in-vitro system do not promote oocyte maturation (Kitai et al., 1985a; Yoshimura et al., 1987; Yoshimura et al., 1988). Higher concentrations of AII were not as effective as lower concentrations in promoting GVBD, suggesting the possibility of down-regulation of AlI receptors. This effect differs from the effects of AII on follicle rupture, in which ovulatory efficiency varied directly with dose of AII throughout the range used. In our system, meiotic resumption induced by AII or hCG was not affected by SAR. In contrast, Palumbo et al. (1988) demonstrated that SAR inhibits meiotic resumption in rats. In rabbit ovary, the All receptors responsible for inducing meiotic resumption may fail to bind SAR; AII may be inducing resumption of meiosis indirectly or via a process that is not receptor mediated.

In summary, AII has a direct effect on the ovary, stimulating both ovulation and oocyte maturation in the absence of gonadotrophin. AlI may play a critical role in the ovulatory cascade initiated by hCG. The effect of AII on meiotic resumption appears to be mediated by a process distinct from that mediating follicle rupture.

We thank Dr F. Naftolin for discussion and critique, Mr R. Ghodgaonkar, Ms B. Smith and Ms L. Dasko for technical assistance, and Ms F. Karas for preparation of the manuscript.

The work was supported in part by NIH grant HD-19430, a SmithKline Beecham Fellowship (T.M. \& K.E.), and the Rockefeller, Lalor, and Lillian and Mitchell Duberstein Foundations.

\section{References}

Ahren, K., Janson, P.O. \& Selstam, G. (1972) Perfusion of ovaries in vitro and in vivo. Acta Endocrinol, Suppl. (Kbh) 158, 285-309.

Culler, M.D., Tarlatzis, B.C., Lightman, A., Fernandez, L.A., DeCherney, A.H., Negro-Vilar, A. \& Naftolin, F. (1986) Angiotensin II-like immunoreactivity in human ovarian follicular fiuid. J. Clin. Endocrinol. Metab. 62, 613-615.

Daud, A.I., Bumpus, F.M. \& Husain, A. (1988) Evidence for selective expression of angiotensin II receptors on atretic follicles in the rat ovary: an autoradiographic study. Endocrinology 122, 2727-2734. 
Daud, A.I., Bumpus, F.M. \& Husain, A. (1989) Angiotensin II: Does it have a direct obligate role in ovulation? Science, N.Y. 245, 870-871.

Fernandez, L.A., Tarlatzis, B.C., Rzasa, P.J., Caride, V.J., Laufer, N., Negro-Vilar, A.F., DeCherney, A.H. \& Naftolin F. (1985) Renin-like activity in ovarian follicular fluid. Fert. Steril. 44, 219-223.

Glorioso, N., Atlas, S.A., Laragh, J.H., Jewelewicz, R. \& Sealey, J.E. (1986) Prorenin in high concentrations in human ovarian follicular fluid. Science, N.Y. 233, $1422-1424$

Husain, A., Bumpus, F.M., De Silva, P. \& Speth, R.C. (1987) Localization of angiotensin II receptors in ovarian follicles and the identification of angiotensin II in rat ovaries. Proc. Natl Acad. Sci., USA 84, 2489-2493.

Kitai, H., Kobayashi, Y., Santulli, R., Wright, K.H. \& Wallach, E.E. (1985a) The relationship between prostaglandins and histamine in the ovulatory process as determined with the in vitro perfused rabbit ovary. Fert. Steril. 43, 646-651.

Kitai, H., Yoshimura, Y., Wright, K.H., Santulli, R. \& Wallach E.E. (1985b) Microvasculature of preovulatory follicles: Comparison of in situ and in vitro perfused rabbit ovaries following stimulation of ovulation. Am. J. Obstet. Gynecol. 152, 889 895.

Kobayashi, Y., Wright, K.H., Santulli, R. \& Wallach, E.E. (1981) Ovulation and ovum maturation in the rabbit ovary perfused in vitro. Biol. Reprod. 24, $483-490$.

Lambertsen, C.J., Jr., Greenbaum, D.F., Wright, K.H. \& Wallach, E.E. (1976) In vitro studies of ovulation in the perfused rabbit ovary. Fert. Steril. 27, 178-187.

Lightman, A., Tarlatzis, B.C., Rzasa, P.J., Culler, M.D., Caride, V.J., Negro-Vilar, A.F., Lennard, D., DeCherney, A.H. \& Naftolin, F. (1987) The ovarian renin-angiotensin system: Renin-like activity and angiotensin II/III immunoreactivity in gonadotropin- stimulated and unstimulated human follicular fluid. Am. J. Obstet. Gynecol. 56, 808-816.

Lightman, A., Jones, C.L., MacLusky, N.J., Palumbo, A., DeCherney, A.H. \& Naftolin, F. (1988) Immunocytochemical localization of angiotensin II immunoreactivity and demonstration of angiotensin II binding in the rat ovary. Am.J. Obstet. Gynecol. 159, $526-530$

National Institutes of Health. (1985) Guide for the care and use of laboratory animals. NIH No. 85-23, US Department of Health and Human Services, Public Health Service.

Palumbo, A., Pellicer, A., DeCherney, A.H. \& Naftolin, F. (1988) Angiotensin action in oocyte maturation in the rat. 35th Annual Meeting of the Society for Gynecologic Investigation, abstr. 107.

Palumbo, A., Jones, C., Lightman, A., Carcangiu, M.L., DeCherney, A.H. \& Naftolin F. (1989) Immunohistochemical localization of renin and angiotensin II in human ovaries. Am. J. Obstet. Gynecol. 160, 8-14.

Pellicer, A., Palumbo, A., DeCherney, A.H. \& Naftolin, F. (1988) Blockage of ovulation by an angiotensin antagonist. Science, N.Y. 240, 1660-1661.

Pucell, A.G., Bumpus, F.M. \& Husain, A. (1987) Rat ovarian angiotensin II receptors. J. biol. Chem. 262, 7076-7080.

Speth, R.C., Bumpus, F.M. \& Husain, A. (1986) Identification of angiotensin II receptors in the rat ovary. Eur. J. Pharmacol. 130, 351-352.

Yoshimura, Y., Santulli, R., Atlas, S.J., Fujii, S. \& Wallach, E.E. (1987) The effects of proteolytic enzymes on in vitro ovulation in the rabbit. $A m . J$. Obstet. Gynecol. 157, 468-475.

Yoshimura, Y., Espey, L., Hosoi, Y., Adachi, T., Atlas, S.J., Ghodgaonkar, R.B., Dubin, N.H. \& Wallach, E.E. (1988) The effects of bradykinin on ovulation and prostaglandin production by the perfused rabbit ovary. Endocrinology 122, $2540-2546$.

Received 10 October 1990 